\title{
The Rise Of Emerging Powers in International Trade and their Impact on Economic and Political Stability
}

\author{
Atreya Mathur ${ }^{1}$, Shilpa Sai ${ }^{1}$
}

\begin{abstract}
In this paper we consider the implications that emerging market economies have on the global economy, with a view to strengthen bilateral ties in trade and promote balanced as well as sustainable growth. There has been a rise and fall in such emerging powers as indicated by the "BRICs"- Brazil, Russia, India and China, resulting in a shift of the economy at a global level, as well as changes in international politics, which have both positive and negative implications. In addition, due to their rapid growth there are changes that can be seen in the structure of trade, production, consumption, capital flow and distribution of power. This article aims at understanding the potential effect BRICs has on the global economy in terms of economic sustainability and illustrates the need for stable economic powers to actively consider sharing the management of international systems and rules. This article analyses the challenges faced by BRICs to manage political and economic growth, while being able to maintain stability, social and political. It provides recommendations for actions that should be taken to effectively deal with the rise of these economies because of possible ramifications they could have on economic and social stability. The study brings out the importance of emerging market economies in international trade and their impact on maintaining economic sustainability at a global level. The research work is predominantly doctrinal in nature. Various research methods, such as Historical method, Analytical method and Evaluative method are employed.
\end{abstract}

Keywords: Emerging powers, BRICs, economic sustainability, political stability, international trade, balanced growth

\section{Introduction}

There have been developments and changes in the economy of the world that has led to the birth of a new concept of international relations. Emerging market economies have created an undeniably strong counter force to the already existing powers impacting the economic and political set up and its stability.

Of all the emerging powers, the BRICs, an acronym coined by O’Neill (2001) for Brazil, Russia, India and China, seem to have the greatest potential to affect the economy at a global level. The countries and their economies are diversified and are also a part of large internal markets, which sets them apart from the other developing countries of the world. They are also the political and economic centers of gravity in their regions, which have enabled them to play a significant global role when it comes to trade especially. However, there has been a setback in the growth of trade due to various incidents over the past few years.

While BRICs brought about the excitement of new world powers, now, its concept seems to be in question. Brazil and Russia are fading away with negative growth rates. While India is moving faster at a rate of $7.5 \%$ per year, it is at a very low base. China is 
the only power, which is moving forward as predicted with a GDP per capita which is four times that of India's.

\subsection{The Slowdown of Global Trade}

With the collapse of the Soviet Union in the 1990's allowing countries like East Germany, Czech Republic and Poland to catch up and rejoin the global economy it slowed down the growth of global trade.

Another factor was when China joined the World Trade Organization in 2001. But their contributions have stabilized after 15 years. The crisis also leads to a slowdown in the global trade and growth. Many companies became more cautious in the market. Consumers were less likely to spend due to the recession. Part of that is also because they'd grown older and they had to rebuild their retirement savings which was a setback. ${ }^{1}$

\subsection{The Positive effects of International Trade on Emerging Countries}

International trade is believed to aggravate inequalities between Western countries and emerging countries. Some would even say that the world economy is dominated by transnational corporations; the only aim of which is to maximise profits without any regard for the development needs of local populations. It is possible that this may be true; however international trade does have more positive effects in emerging countries.

First of all, international trade can help reduce poverty. The best example could of course be that of China. The country experienced a phenomenal growth in GDP due to increasing international trade relations from the year $2000-2012$ from a rate at $8.7 \%$ to a rate of $19.3 \%$.

International trade creates great opportunities for emerging companies to enter into markets around the world. Growing countries can also develop businesses and become part of international production networks and supply chains which would lead to the expansion of the businesses.

It has also become more cost effective for emerging countries to enter into the global market due to advancement in telecommunications and the internet which facilitate transfer of service jobs to less developed countries.

International trade could also lead to greater access to capital flows. One of the countries that benefits the most from this is Indonesia, with a net foreign direct and portfolio investment total of US $\$ 23.2$ billion in 2013, according to official balance of payments (BOP) data. ${ }^{2}$

It cannot be denied that the emerging countries which are engaged in international trade networks can be seen to have a larger growth rate than others not taking part. Measures have to be taken so as to ensure that the benefits of international trade which is just and fair is distributed and shared more equally.

\section{The BRICs}

\footnotetext{
${ }^{1}$ Kimberley, A. (2017, October 6).International Trade: Pros, Cons, Effect on Economy. Retrieved from https://www.thebalance.com/international-trade-pros-cons-effect-on-economy-3305579

2 The Positive Effects of International Trade on Emerging Countries, European Movement International. (2015, June 4) Retrieved from http://europeanmovement.eu/news/the-positive-effects-of-international-trade-on-emerging-countries/
} 
Majority of the BRICs have a long way to go before becoming major powers of the world. While the United States has \$57,000 GDP per capita, the BRICs' GDP per capita ranges from low levels of $\$ 1,500$ (India) and $\$ 6,800$ (China) to modest levels of $\$ 11,200$ (Brazil) and Russia (\$14,600).

There is also corruption at a large scale which plays a major role in stunting economic growth. Corruption drains away needed money for development and investment while harming the ability of businessmen to attract market share from corrupt enterprises.Earlier it was assumed that these countries would peacefully ascent into world powers but this has not come into play. The leading economic powers have been more or less modern, democratic states that were governed under the rule of law while the BRICs were often under colonial rules.

While Brazil and Russia seem to be fading, and India growing at an extremely slow pace, there really doesn't seem to be the concept of a "BRICs" empire any more. Rather a single country; China that could become a superpower by 2040. China has become the number one market for automobiles and has over $\$ 3.5$ trillion in government reserves along with an incredible work ethic and significant investment in infrastructure. With the help from Overseas it gives the emerging power a strong chance to become a superpower.

\subsection{The Brazilian Job}

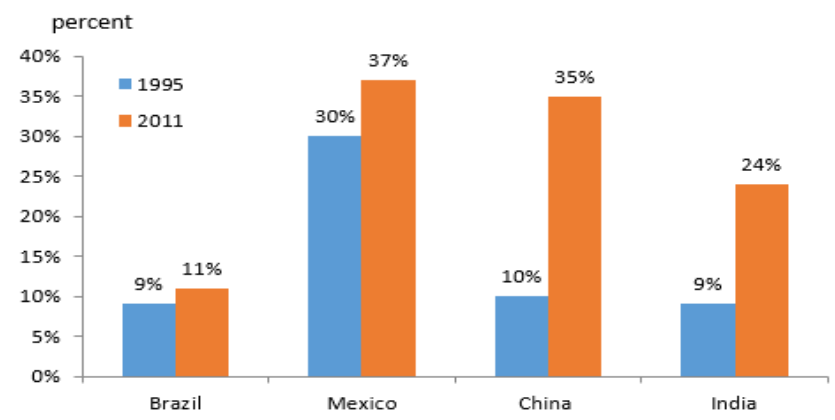

Figure 1: Imported value-added content in manufacturing exports. Source: World Input-Output Database.

Brazilian foreign trade has decreased since 2013, both in nominal terms and as a percentage of the GDP. The country's foreign trade volume decreased by $33 \%$ between 2013 and 2016, from US\$481 billion to US\$322 billion. Relative to GDP, foreign trade declined from 19.6\% in 2013 to $18.2 \%$ (estimate) in 2016. The share of Brazilian exports in global trade decreased from $1.33 \%$ in 2013 to $1.21 \%$ in 2015 . However, the number of exporting firms expanded $18.1 \%$ in this period, reaching 22,205 companies in 2016 related to special operations. ${ }^{3}$

The main challenges faced by Brazil are:

a. Establishing the True Size of Brazil's Fiscal Problems - Brazil's new Finance Minister,

${ }^{3}$ Trade Policy Review by Brazil, World Trade Organization (June 12, 2017). 
Henrique Meirelles, already conceded in a recent interview that this year's primary deficit—revenues minus expenditures, excluding interest payments on the debt—is likely to exceed 2 percent of GDP, the as-yet-unapproved target that Dilma Rousseff was trying to pass through Brazil's Congress. ${ }^{4}$

b. Putting a Break on Expenditure Growth - In view of the sizeable deficit, and the constraints to adopting a substantial short-term fiscal adjustment, restraining expenditure growth is of paramount importance. ${ }^{5}$

c. Renegotiating State Debts with the Federal Government - As a result of Brazil's deep recession, as well as a substantial weakening of the fiscal responsibility framework at the state level, sub-national finances are in dire straits. ${ }^{6}$

d. Outlining a Trade Agenda and Strategy - Over the past two decades, Brazil has been increasingly isolated from the global economy. According to various measures of trade openness, it remains one of the most closed economies in the world. ${ }^{7}$

Even through the harsh economic times, Brazil continues to uphold and reinforce the rules-based Multilateral Trading System and reaffirm the relevance of the WTO as one of the central pillars of the global economic governance.

As seen in figure 2, Brazilian exports have remained mostly "made in Brazil," while the emerging economies today boast an export base that is largely "made in the world." 8 Brazil's foremost concern should be to eliminate the factors that keep away foreign investments. The "made in Brazil" concept is good to promote indigenous growth of industries, but in order to develop one's economy, foreign investment is equally important to keep the international trade relations alive.

Brazil presupposes that the notion of competitiveness must be considered at a global level. The Brazilian Government is executing an important scheme to promote productivity and competitiveness in addition to the economic modification that is currently in progress. The Brazilian government's vigor and devotion to achieve openness in international trade, reduction of bureaucracy, magnetizing investment and augmentation of innovation and productivity is reflected by this plan.

The new Brazilian government has put trade at the top of its agenda by placing Brazil's export promotion agencies directly under the presidency and the Ministry for Foreign Affairs. ${ }^{9}$ In addition to outlining a new policy for Brazil's relations with the dysfunctional Mercosur, the Pacific Alliance, the United States, and the European Union, it should also lay down the foundation for trade facilitation agreements that could help alleviate some of the country's economic discord, even if it is no panacea for reinstating sustainable medium-term growth.

${ }^{4}$ Bolle M. D., Five Challenges Facing Brazil's new Government, Peterson Institute for International Economics, Retrieved from https://piie.com/blogs/realtime-economic-issues-watch/five-challenges-facing-brazils-new-government.

${ }^{5}$ Bolle M. D., Five Challenges Facing Brazil's new Government, Peterson Institute for International Economics, Retrieved from https://piie.com/blogs/realtime-economic-issues-watch/five-challenges-facing-brazils-new-government.

${ }^{6}$ Bolle M. D., Five Challenges Facing Brazil's new Government, Peterson Institute for International Economics, Retrieved from https://piie.com/blogs/realtime-economic-issues-watch/five-challenges-facing-brazils-new-government.

${ }^{7}$ Bolle M. D., Five Challenges Facing Brazil's new Government, Peterson Institute for International Economics, Retrieved from https://piie.com/blogs/realtime-economic-issues-watch/five-challenges-facing-brazils-new-government.

${ }^{8}$ Bolle M. D., Five Challenges Facing Brazil's new Government, Peterson Institute for International Economics, Retrieved from https://piie.com/blogs/realtime-economic-issues-watch/five-challenges-facing-brazils-new-government.

${ }^{9}$ Bolle M. D., Five Challenges Facing Brazil's new Government, Peterson Institute for International Economics, Retrieved from https://piie.com/blogs/realtime-economic-issues-watch/five-challenges-facing-brazils-new-government. 


\subsection{The Russian Avant-Garde}

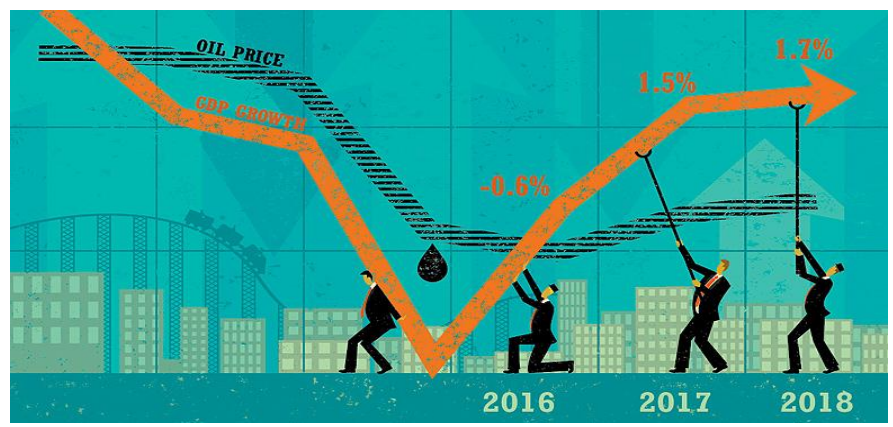

Figure 2: Growth of Russia's GDP in relation to the drop in Oil Prices

There is no aspect of contemporary Russia that has changed more rapidly and unexpectedly than its political and economic situation.

When Vladimir Putin became President, Russia was effectively bankrupt as it owed more money to the International Monetary Fund (IMF) than it had in foreign currency reserves. Since then, Russia has achieved a virtual macroeconomic revolution to the point where it is one of the largest creditors of U.S. debt in the world. Its nominal dollar GDP has increased by more than a factor of six, and has the potential to reach more than $\$ 2$ trillion by 2010 . Growth of this magnitude would equate to nearly a ten-fold increase in GDP over the course of a decade. ${ }^{10}$

Regarding its trade pattern, the main challenges include:

a. Narrowing the productivity gap between Russian and Western firms and industries; to attract more domestic and foreign investment; and, underlying these goals, to implement the judicial, administrative, social, and banking reforms necessary to future growth. ${ }^{11}$

b. An extremely large share of mineral resources in trade in goods, high level of dependency on oil and gas prices;

c. A very modest portion of machinery in exports;

d. A weak participation in international industrial value chains;

e. Vulnerability in terms of food security and agricultural production; and

f. A high level of openness combined with a high level of import concentration ${ }^{12}$

Foreign trade is of vital importance to Russia which, by international standards is already quite open. The open trade environment along with the increasingly high levels of export and import concentration have made the country prone to fluctuations abroad and to changes in the competitive environment.

Policy makers should be make and effort towards increasing the geographical and product diversification of exports including through the support of the country's quest

10 Economic Change in Russia, Center for Strategic and International Studies. Retrieved from https://www.csis.org/programs/russia-and-eurasia-program/russia-and-eurasia-past-projects/economic-change-russia

${ }^{11 B}$ Berglöf Erik, Andrei Kunov, Julia Shvets, KsneiaYuaeva. (2003) The New Political Economy of Russia.

${ }^{12}$ Sergei F. Sutyrin, Alexandra G. Koval and Olga Y. Tromenko. (2016) Russian Foreign Trade as an Issue for National Policy Makers. Retrieved from https://www.wto.org/english/tratop_e/devel_e/train_e/Russia.pdf 
for a modernization and "innovation based" model of development. ${ }^{13}$

The prevailing conditions of the economy create opportunities as well as threats for the development of business within the country and specifically for international trade.

There have also been multidirectional effects on international trade after Russia's WTO accession and new membership in customs unions.

As seen in Figure 2, The GDP has increased in 2018 with the drop in the price of oil but in the short run, one cannot expect that trade policy measures undertaken in Russia will have a major positive impact on the country's industrial structure. Fundamental changes are required at a much deeper level along with changes in the institutional framework at a national level with combined effort from domestic companies that should object at increasing competitiveness and large scale modernization.

\subsection{Namaste, India}

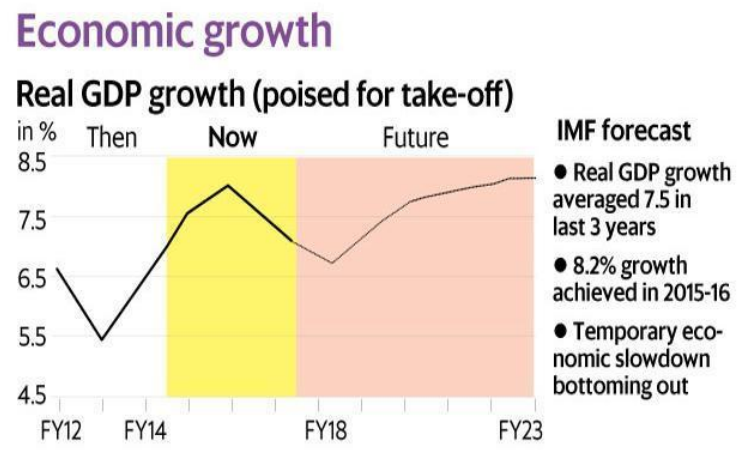

Figure 3: India's Economic Growth in terms of its Gross Domestic Product

Source: LiveMint.com

Enhanced by the forthcoming Foreign Trade Policy, India's exports are anticipated to reach US\$ 750 billion by 2018-2019 according to Federation of India Export Organisation (FIEO) ${ }^{14}$. The Indian Government is making significant treaties with the governments of Japan, Australia, and China because of which the external sector's contribution to the economic development of the country and growth in the global markets is increasing. Furthermore, by executing the Foreign Trade Policy 2014-19, by 2020 , it is expected that India's stake in world trade is going to double from the present level of three percent.

India's present position in International Trade:

a. Mr Richard Verma, the United States Ambassador to India, has verified that India-US relations across trade, defence and social ties will be among the top priorities of the newly elected US President Mr Donald Trump's administration. ${ }^{15}$

\footnotetext{
${ }^{13}$ Sergei F. Sutyrin, Alexandra G. Koval and Olga Y. Tromenko. (2016) Russian Foreign Trade as an Issue for National Policy Makers. Retrieved from https://www.wto.org/english/tratop_e/devel_e/train_e/Russia.pdf

${ }^{14}$ Sergei F. Sutyrin, Alexandra G. Koval and Olga Y. Tromenko. (2016) Russian Foreign Trade as an Issue for National Policy Makers. Retrieved from https://www.wto.org/english/tratop_e/devel_e/train_e/Russia.pdf

${ }^{15}$ Foreign Trade Policy of India, India Brand Equity Foundation.(2018) Retrieved from https://www.ibef.org/economy/trade-and-external-sector
} 
b. The Union Cabinet has approved a Memorandum of Understanding (MoU) between India and the Russian Federation, aimed at expanding bilateral trade and economic cooperation between the two countries. ${ }^{16}$

c. The Union Cabinet has approved a MoU between India and Uruguay concerning cooperation and assistance in customs related issues, which is expected to promote trade and facilitate efficient clearance of goods traded between the countries. ${ }^{17}$

d. India and Japan are seeking to put up a network to connect the Pacific and the Indian Ocean, aimed at contributing to Asian stability by utilising India's political network in African and Japanese funds in order to finance and develop a variety of projects across the African continent. ${ }^{18}$

e. India and Kenya have signed seven agreements, such as in the fields of double taxation avoidance and defence cooperation, to strengthen the bilateral relations, which will also be boosted by the Indian government extending the concession line of credit of US\$ 44.95 million to Small and Medium Enterprises (SMEs) and textile industry of Kenya. ${ }^{19}$

f. The Government of India has successfully completed the double taxation avoidance agreement (DTAA) negotiations with the Government of Cyprus, which is expected to further develop the trade and economic links between the two countries. ${ }^{20}$

India is currently acknowledged as one of the most significant competitors in the international economic backdrop. The government policies, strategies for international trade, and the inherent economic power that India possesses, have accredited to its position as one of the most sought- after destinations for overseas investments in the world.

Even though the Government is entering into treaties with the governments of other countries, the major challenge that India faces is that of lack of adequate labour force to bring into effect the said treaties into practice. Until and unless the bilateral or multilateral ties between the countries are implemented, there is no actual progress taking place, and in order for that to happen, a strong labour force is required.

This has a negative impact on the global trade as, treaties come with certain expectations from the contracting State, which are not met because the requisite results are not achieved out of the formation of treaty which lowers the image of India in the International scenario.

At present the Indian labour force consists mostly of skilled and unskilled male-labourers only. The women of India, due to cultural differences (though most of them are breaking that taboo and are exploring the world outside of their homes) are often discouraged from working outside their homes and are restricted to household work. These restrictions and taboos surrounding the women are placing the country's development at a disadvantage, because it is literally halving the possible labour force that it could ideally

\footnotetext{
${ }^{16}$ Foreign Trade Policy of India, India Brand Equity Foundation. (2018) Retrieved from https://www.ibef.org/economy/trade-and-external-sector

${ }^{17}$ Foreign Trade Policy of India, India Brand Equity Foundation. (2018) Retrieved from https://www.ibef.org/economy/trade-and-external-sector

${ }^{18}$ Foreign Trade Policy of India, India Brand Equity Foundation. (2018) Retrieved from https://www.ibef.org/economy/trade-and-external-sector

${ }^{19}$ Foreign Trade Policy of India, India Brand Equity Foundation. (2018) Retrieved from https://www.ibef.org/economy/trade-and-external-sector

${ }^{20}$ Foreign Trade Policy of India, India Brand Equity Foundation.(2018) Retrieved from https://www.ibef.org/economy/trade-and-external-sector
} 
possess. According to reports, if women'sinvolvement were to increase, it could boost India's economy to a double digit growth.

India is doing great at the International level, but what is actually hindering its development or rather, impeding its faster growth, is an issue back at home. As discussed, the insufficiency of labour force is the reason why. The government of India should develop or formulate programs that would encourage women to take up jobs and become active participants of the labour force which would improve the overall growth of the economy which would in turn help India reach the "developed country" status.

As seen in Figure 3, the GDP was the highest during 2014-2018 and took a hit in 2018. The analysts say that the economic policy changes that were introduced by the ruling party government in the financial year 2017-2018 had disturbed the economy momentarily as those changed were not anticipated. Nevertheless, this is a temporary economic slowdown and it has been predicted that by financial year 2023, the economic growth will catch up its pace and start to rise again, simply by going by the statistics of the previous policy changes that, it takes time for an economic policy to show its effect.

\subsection{The Chinese Boom}

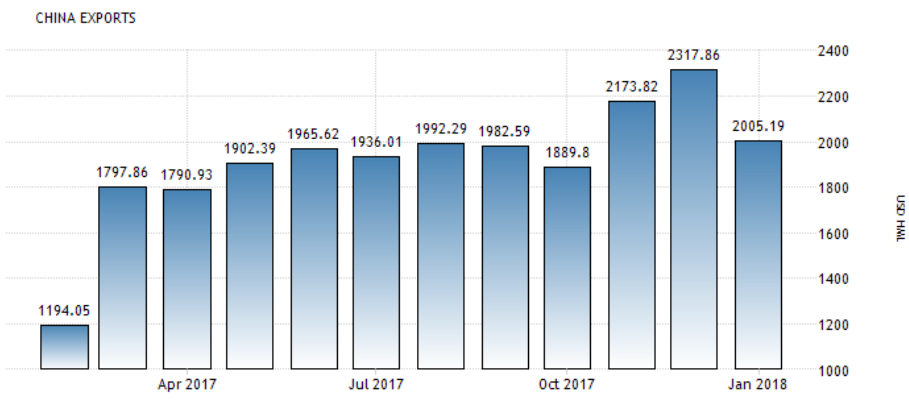

Figure 4: China's Export Statisticsof 2017; Source: Tradingeconomics.com

In 2014, China became the biggest trading power as well as the biggest inward Foreign Direct Investment recipient country in the world. In the last thirty-five years, and through unassailable expansion plan and on-going institutional restructuring, China has made a remarkable economic and trade performance.

In specific, China's joining the WTO in 2001 and fully engaging in regional and bilateral trade agreements in recent years provided a striking momentum for its rule-based, market-oriented trade and investment liberalization. In November 2013, the new Chinese leadership's focus on deepening economic reform in China led to a milestone Decision reached at the Third Plenum of the 18th Central Committee of the Chinese Communist Party (CCP), which depicted the vision of comprehensive and far-reaching economic reform in the near future.

The expected reforms are also considered as strategic response to address the emerging trading rules and disciplines, focusing on regulatory coherence, which are intensively negotiated in some mega-regional trade pacts,such as the Trans Pacific Partnership 
(TPP) and Transatlantic Trade and Investment Partnership (TTIP). ${ }^{21}$

The main challenges that are faced by China are:

a. Falling Growth Rate: Chinese economic growth rate has been unprecedented. The economy has been growing over $10 \%$ per annum for a couple of decades now. However, since the Chinese economy is centrally planned, the government is responsible for planning the growth rate as well. Hence, this growth rate was largely fuelled by the very ambitious infrastructure projects that were undertaken by the government of China. However, these infrastructure projects also caused a lot of debt. Over the years, the economy became overburdened with this debt. Now since the market sentiment is negative and more debt cannot be added, the growth rate has started crumbling. The most recent statistic has shown growth rate to be close to $6.5 \%$ and this has already started causing investor panic based on fears that this number could dip even further if the Chinese are not able to find another cheaper source of funds to fuel their growth ambitions. $^{22}$

b. Heavy dependence on investment to fuel growth: Investment accounts for around $47 \%$ of GDP, an astoundingly high figure. But the large amount of excess capacity and declining profitability are dampening spirits. Were it not for government-driven infrastructure spending, state enterprise-led expansion of favoured industries, euphoric levels of investment in exciting technologies and the revival in real estate investment, a fall in investment could have tipped the Chinese economy into recession. But, as the real estate sector heats up and inflation rises, policymakers have to cut back on stimulus. ${ }^{23}$

c. The long-term policy: Some fear that the shift to an industrial policy favouring local champions could compromise the flow of foreign technology and capital that has been crucial to China's development - or it could provoke retaliation from trading partners. ${ }^{24}$ China's outstanding performance in economic growth can be traced back to its increasing involvement in global trade and dynamic trade policy. China's rapid economic growth has made the country target the world as its market. Theincreasing participation in the global market helps China reap the static and dynamic benefits from trade, facilitating the rapid national economic growth ${ }^{25}$.

China's access to technology-intensive intermediate goods has proved to have significantly enhanced its productivity in the processing sectors. As a result, the development of domestic technological capability has been driven by China's area of expertise in processing industries.Nonetheless, there are still some problems that China is facing, like, low domestic absorptive capability and unbalanced development pattern.The Chinese institutional decision-making process of trade policy, similar to

${ }^{21}$ Bin S., China's Trade Development Strategy and Trade Policy Reforms : Overview and Prospect, The Institute of International Economics, Nankai University, Tianjin, China, P.R.

22 Top Five Challenges Facing the Chinese Economy, Management Study Guide, retrieved from https://www.managementstudyguide.com/top-five-challenges-facing-the-chinese-economy.htm.

${ }^{23}$ Bhaskaran M., The Challenges Facing China’s Economy, Accounting Business Magazine, The Association of Certified Chartered Accountants, retrieved from http://www.accaglobal.com/in/en/member/member/accountingbusiness/2017/05/in-focus/china-economy.html.

${ }^{24}$ Bhaskaran M., The Challenges Facing China’s Economy, Accounting Business Magazine, The Association of Certified Chartered Accountants, retrieved from http://www.accaglobal.com/in/en/member/member/accountingbusiness/2017/05/in-focus/china-economy.html.

${ }^{25}$ Sun P. and Heshmati A., International Trade and its Effects on Economic Growth in China, Discussion Paper Series, IZA DP No. 5151 
other countries, is inexorably prejudiced by an array of interest groups with Chinese characteristics, namely the central government, local governments, state-owned enterprises, business associations and other stakeholders ${ }^{26}$.

Furthermore, with China increasingly integrating into the world economy, it is confronted with demanding challenges growingly, of foreign interests including a rulebased and institutionalized world trading system, international and regional collective actions, and bilateral economic dialogues and trade negotiations ${ }^{27}$.

Hence, China's trading policy has had a profound influence by diplomatic strategies of foreign governments; trade politics of parties, multinational corporations' commercial interest and opinions of public.

What the Chinese government should ideally do now is to change their economic policy in such ways that it paves way for local markets to come up, rather than completely relying on Foreign Direct Investments. India which is a close competitor to China has potential to overtake it in international trade and divert all the investments to it. No country should ever be completely reliant only on Foreign Direct Investment as it is an extremely volatile external factor. It has been proving to be good for it, so far, but it is highly unpredictable about what could happen next and thus China should amend its policies before it faces an economic meltdown.

As seen in Figure 4, the export statistics of China are very promising. China's economy is currently thriving due to its manufacturing potential. It has been predicted that, soon, the manufacturing sector of China will lose its demand due to alternative upcoming market in the sub-continent - India. China needs an improved scheme of market-oriented restructuring to advance domestic growth and lessen weight on the global economic system.

\section{The Challenge}

In order to ensure stability and equality in distribution, there are various challenges that have to be faced by the BRICs economies to manage their growth and find their place in the international marketplace.

\subsection{Stability}

The first and foremost challenge that is faced by the BRICs economies and more over, the policy makers, is that of ensuring that political and economic stability is maintained. There has been rapid growth and development that has lead to ever increasing changes in the economic sector along with the modernisation of the political sphere. Something that all the countries share is the challenge of coping with the ever growing inequalities while ensuring that the employment growth continues at a stable pace.

\footnotetext{
${ }^{26}$ Sun P. and Heshmati A., International Trade and its Effects on Economic Growth in China, Discussion Paper Series,IZA DP No. 5151

${ }^{27}$ Sun P. and Heshmati A., International Trade and its Effects on Economic Growth in China, Discussion Paper Series,IZA DP No. 5151
} 


\subsection{Sustainability}

Another challenge is that of making sure that the growth of the country is consonance with the policy of sustainability. The depletion of natural resources, the pollution and climate change have to be taken into consideration where eco-friendly solutions should be included in the policies of trade.

\subsection{Institutional Mechanisms}

In order to take on the economic, political and environmental challenges, there is also the challenge of establishing institutional mechanisms which are strong and sustainable to provide for effective crisis control and regulation, supervision systems and safety nets to deal with the shocks that could be of a large proportion taking into account the size of the countries.

\section{Recommendations for Action}

To effectively deal with the challenges so put forth to the BRICs, it is imperative the countries respond to ensure stability and sustainability.

\subsection{The Bigger Picture of the BRICs Empire}

There should firstly be awareness and knowledge created of the political and economic trends with respect to the BRICs. The G7 should take measures to evolve relations and understand the countries independently. Bilateral ties can be built while democratic as well as international voices strengthened by the creation of business and societal links along side with the government.

\subsection{Increase the role and stakes of BRICs in Institutions}

BRICs countries need to be included in international organisations and should be given a greater stake in such institutions where they can be given a voice and power for making important decisions. There should be promotion of sharing the overall cost of global governance institutions.

\subsection{Balanced and Sustainable Growth}

The G7 should encourage the adoption of growth strategies which are ecofriendly and minimize environmental degradation. International human right norms, social responsibility standards and the use of cleaner and efficient technology must be promoted for. The participation of the BRIC's must be aggressively pursued to adopt such strategies.

\subsection{Competitive Policies}

The policy makers must adopt and develop policies which facilitate the mobility into different growth sectors in this era of globalisation and dynamism. It is critical that leaders in the political sphere of higher wage economies take steps proactively so as to develop such policies while ensuring that there is a provision for social insurance to all those who have been disturbed and displaced in this dynamic era of globalisation. 


\section{Conclusion}

It can be seen through the course of this paper that the emerging powers construed in the concept of the BRICs Empire seem to have the greatest potential to affect the economy of the world.

The countries face tremendous challenges to manage their growth and their evolutionpolitically and economically while ensuring a level of sustainability to secure their stance in the global market along with other larger emerging economies. In the reign of economical and political complexities at both national and global levels, these economies must effectively respond to these challenges, as must the $G 7$ nations to help shape this evolution in the most positive way possible.

So as to ensure that the emerging economies are in consonance with the necessary element of sustainability- politically and economically, the BRICs must be given more importance in the international sector. The role of the BRICs and the stakes that the rising powers have in institutions should be increased and paid heed to. Moreover, there should be competitive policies drafted which go hand in hand with the dynamic character of the global economy.

With their service- providing and manufacturing powerhouses, India and China along with Brazil and Russia with these economies being major suppliers of raw materials and energy it can be concluded that at least one or two of the BRIC's will ultimately rank among the leading players in the global economy. 